\title{
On The Effects of Scale Economies and Import Barriers on Brazilian Trade Performance and Growth: An Interstate CGE Analysis
}

\author{
Lucas P. do C. Ferraz ${ }^{\mathrm{a}}$, Eduardo A. Haddad ${ }^{\mathrm{b}}$ \\ ${ }^{\mathrm{a}}$ EESP-FGV, Getúlio Vargas Foundation, Brazil \\ ${ }^{b}$ FEA, University of São Paulo, Brazil
}

ÁREA 6: Economia Internacional; Classificação JEL: F17;F12

\begin{abstract}
Economists generally pay little attention to the effects of liberal trade policies on the internal geography of countries. This paper presents a fully operational interstate CGE model implemented for the Brazilian economy that examines how the distribution of the economic activity may change as the country opens up to foreign trade. Among the distinctive features embedded in the model, modeling of scale economies, port efficiency and land-maritime transport costs provides an innovative way of dealing explicitly with theoretical issues related to integrated regional systems. In order to illustrate the role played by the quality of infrastructure and geography on the country's foreign and interregional trade performance, a set of simulations are presented where import barriers are significantly reduced. The relative importance of import tariffs, port efficiency and maritime transport costs for the country trade relations and regional growth is then detailed and quantified. A final set of simulations shed some light on the spatial effects of scale economies, where the manufacturing sector in the state of São Paulo, taken as the core of industrial activity in the country, is subjected to different levels of increasing returns to scale at the firm level. Coreperiphery effects are then traced out suggesting the prevalence of agglomeration forces over diversion forces could rather exacerbate regional inequality as import barriers are removed up to a certain level. Further removals can reverse this balance in favor of diversion forces, implying de-concentration of economic activity as the country opens up to foreign trade, a result quite in line with recent advances in NEG models.
\end{abstract}

Keywords: Economic Geography, CGE model; Port efficiency; Land-maritime transportation costs

\section{Resumo}

Os economistas, em geral, dão pouca atenção aos efeitos de políticas liberais de comércio na geografia interna dos países. Este artigo apresenta um modelo de Equilíbrio Geral Computável interestadual, totalmente operacional, calibrado para a economia brasileira, o qual examina de que forma a distribuição da atividade econômica pode variar, quando um país se abre ao comércio internacional. Dentre as características de maior destaque presentes no modelo, a modelagem de economias de escala, eficiência portuária e custos de transporte terrestres e marítimos proporcionam uma maneira inovadora de lidar, explicitamente, com questões teóricas relacionadas a sistemas regionais integrados. Visando ilustrar o papel desempenhado pela qualidade da infra-estrutura e da geografia econômica na performance de comércio inter-regional e internacional do país, um conjunto de simulações é apresentado, onde as barreiras de importação são significativamente reduzidas. A importância relativa de tarifas de importação, eficiência portuária e custo de transporte marítimo, para as relações de comércio do país e seu crescimento regional, é, então, detalhada e quantificada. Um conjunto final de simulações discute os efeitos espaciais das economias de escala, onde o setor de manufaturas do estado de São Paulo, considerado o núcleo da atividade industrial no país, é sujeito a diferentes níveis de retornos crescentes de escala no âmbito das firmas. Efeitos do tipo "Centro-Periferia" são detectados e caracterizados, sugerindo que a predominância de forças de aglomeração sobre forças de dispersão podem mesmo exacerbar a desigualdade regional existente no país, na medida em que as barreiras de importação são removidas até um determinado nível. Maiores níveis de abertura podem reverter este equilíbrio em favor das forças de dispersão, implicando em desconcentração da atividade econômica na medida em que o país se abre unilateralmente ao comércio internacional, um resultado em linha com avanços recentes alcançados pelos modelos da Nova Geografia econômica.

Palavras-chave: Geografia Econômica; Modelos EGC; Eficiência portuária; Custos de transporte marítimos e terrestres. 


\title{
On The Effects of Scale Economies and Import Barriers on Brazilian Trade Performance and Growth: An Interstate CGE Analysis
}

\author{
L. P. do C. Ferraz, E. A. Haddad
}

\section{Introduction}

The improvement of a country's trade performance and of its ability to participate fully in the world economy entails a great understanding of the interplay between trade and trade costs and the magnitude of the barriers to trade that they create. Trade costs can be broadly divided into several categories or dimensions, including some of the most commonly investigated such as tariffs, transport costs, costs of delays and uncertainty of delivery, just to mention a few.

For most of the post-war period, tariff reduction had been the focus of bilateral and multilateral trade talks among countries worldwide. For instance, Asia has reduced its average tariff rate from 30 percent at the beginning of the 1980s to 14 percent by the end of the 1990s, and Latin America has reduced its average tariff rate from 31 percent to 11 percent through the same period. Since 1950, the average US import tariff rate has dropped from 6.0 to 1.5 percent. Also, between 1960 and 1995 worldwide average import tariff rate has dropped from 8.6 to 3.2 percent (Clemens and Williamson, 2002). As liberalization continues to reduce artificial trade barriers, other categories of trade costs began to receive greater consideration by international trade economists. Nowadays it is widely accepted that the effective rate of protection provided by, for example, transport costs is, in many cases, considerably higher than that provided by tariffs.

From 1950-2004, world trade grew at a rapid average rate of 5.9 percent per annum. The annual growth rate of manufacturing trade was even faster, at 7.2 percent. For the world as a whole, the ratio of trade relative to output more than tripled over the last five decades (WTO, 2005). According to Hummels (2007), besides tariff reduction "one possible explanation for the rise in international trade is a decline in international transportation costs. The economic effects of improved transportation are apparent not only in how much trade has grown, but also in how trade has grown. Improvements in the quality of transportation services - like greater speed and reliability - allow corresponding reorganizations of global networks of production and new ways of coping with uncertainty in foreign markets”.

A study of the World Bank (2001) shows that for 168 out of 216 US trading partners, transport costs barriers outweighed tariff barriers. For the majority of Sub-Saharan African countries, transport costs incidence for exports (the share of international shipping costs in the value of trade) is 5 times higher than tariff cost incidence (the trade weighted ad valorem duty actually paid). Similarly, for many countries in Latin America and the Caribbean, transport costs account for a larger share than tariffs in the import price. Moreover, freight costs in developing countries are on average 70 per cent higher than in developed countries, and they are the highest in Africa, where they are twice the world average.

In 1997, total import freight costs represented 5.25\% of world imports. This percentage, which may seem low, is mainly driven by developed countries, which represent more than 70 percent of world imports and whose proximity to each other is reflected in a relatively low freight cost (4.2\%). When disaggregating these costs by region, they turn out to be substantially higher. Although Latin America appears to have low freight costs relative to the other developing regions (7\% compared to $8 \%$ for Asia and $11.5 \%$ for Africa), the Latin American figure is weighted by Mexico's proximity to its main trading partner, the United States, and consequently low freight costs. When Mexico is excluded, Latin America average freight costs rise to 8.3\%, more similar to the rest of the developing countries. For some countries such as Chile and Ecuador, maritime freight rates (CIF-price/FOB-price) exceed by more than twenty times the average tariffs they face in the US market (Clark et al, 2004). 
How much do trade costs affect the trade performance of a country? How much do these costs can be minimized by sound government trade policy? Taking transport costs as a starting point, the broad literature shows that transport costs depend both on countries' geography and on their levels of infrastructure. The geographical measures generally considered in the literature are distance between countries, remoteness (distance from the biggest markets), whether countries share a common border and whether countries are landlocked or are islands. According to Limão and Venables (2000) landlocked countries on average in 1995 had an import share in GDP of $11 \%$, compared to $28 \%$ for coastal economies. Of the top 15 non-primary export performers in 1965-1990, eight were island and none were landlocked countries. The infrastructure measures are typically related to the quality of transport and communications infrastructure. Although the importance of infrastructure for transport costs is already well established in regional and transport economics, most of the empirical studies on the impacts of international transport costs for bilateral trade often neglect this point and focus on geographical and product characteristics instead.

The determinants of transport costs and its impacts on bilateral trade between countries have been extensively investigated in the recent empirical literature (Hummels, 2007; Hummels, 2001a, Hummels, 2001b, Limão and Venables, 2001). In most of the cases, gravity models are the standard analytical framework used for the estimation of the role of transport costs in explaining bilateral trade flows.

In an attempt to go a step further on the estimation of transport costs, the characterization of its determinants and its impacts on bilateral trade, Limão and Venables (2001) construct an infrastructure quality index that, together with some geographical variables, could better explain transport costs. According to the results presented, the quality of infrastructure is able to explain $40 \%$ of predicted transport costs for coastal countries, and up to $60 \%$ for landlocked countries. Based on a broad IMF international data set, the infrastructure quality index is composed as an average of the density of the road network, the paved road network, the rail network, and the number of telephone main lines per person in each country available in the sample. In a second step, the authors evaluate the extent to which transport costs impacts on the trade performance of a country. They undertake a gravity model exercise, incorporating the same geographical and infrastructure measures that they used in estimating transport costs. This analysis confirms the importance of these variables in determining bilateral trade, and also enables the authors to compute estimates of the elasticity of trade flows with respect to transport costs. Accordingly, a 10 percentage point increase in transport costs typically reduces trade volumes by approximately 20\%. Taken as a whole, the work by Limão and Venables provides a rather consistent picture of the determinants of transport costs, and in particular of the importance of infrastructure in source and destination countries as well as in any transit countries used by landlocked countries.

Hummels (2001a) calls attention for the possible allocation effects in bilateral trade due to transport costs. Using a comprehensive international trade data set, the author shows that freight rates have, in general, higher means and variances than tariff rates for the countries in the sample. Also, aggregate expenditures on freight are on the low end of a wide range of observed rates. This suggests that the aggregate rates significantly understate shipping costs borne by most exporters and that transportation costs play a significantly allocative role in bilateral trade. In other words, aggregate freight expenditures are low because import choices are made to minimize transport costs. The paper allows a complete characterization of trade costs implied by trade flows and a partition of those costs into three components: explicitly measured costs (tariffs and freight), costs associated with common proxy variables (geography and infrastructure), and costs that are implied but unmeasured. Explicitly measured costs are, according to the author, most of the story.

It is well known that some Asian countries such as Singapore and Hong Kong have the most efficient ports in the world, while some of the most inefficient are located in Africa (Ethiopia, Nigeria) or South America (Colombia, Venezuela and Ecuador). Considering specifically the role of the quality of infrastructure on trade performance, there seems to have a wide consensus on the crucial importance of 
port activities for the transport services, especially maritime transport services. Regarding the causality relationship between port efficiency and maritime transport costs, Clark et al (2004), using a data set from the "Global Competitiveness Report" (an aggregate measure, per country, of port efficiency, consisting of a one-to-seven index) find that improving port efficiency from the $25^{\text {th }}$ to $75^{\text {th }}$ percentiles reduces shipping costs by more than $12 \%$. The coefficient on port efficiency is negative and highly significant for all regressions carried out and this result is also robust to different proxies of port efficiency used in the estimations, such as the number of large seaports in the country, its per capita GDP or an infrastructure quality index. According to the results, if countries like Ecuador, India or Brazil improved their port efficiency from their current level to the $75^{\text {th }}$ percentile, that is, to a level attained by countries like France or Sweden, they would reduce their maritime transport costs by more than $15 \%$ each. Clark et al also find that insurance fees represent around 15\% of total maritime charges, suggesting that high value added exporting countries should have higher charges per unit weight due to this insurance component. On the other hand, some products require special transport features (frozen products, for instance) and therefore have different freight rates. The authors also find that the level of infrastructure (measured as a quality index) and organized crime exert a significant positive and negative influence, respectively, on port efficiency. Moreover, policy variables reflecting regulations at seaports affect port efficiency in a nonlinear way, suggesting that having some level of regulation increases port efficiency, but an excess of regulation could start reversing these gains.

Another very important dimension of trade costs is time. For instance, poor port infrastructure or inadequate port handling capacity may cause long delays that are not necessarily reflected in the monetary outlays on transport services. The same is valid for red tape at customs. According to Nordas and Piermartini (2004) lower tariff costs have made fragmentation of the production process possible (vertical integration). The resulted increased trade in intermediate products has in turn driven demand for timely and effective transport and logistics services. Therefore, since timeliness seems to have become very important, the authors argue that geography and the quality of infrastructure probably matter even more for timeliness than for freight rates.

Djankov et al (2006) use a World Bank data set on the time it takes to move containerized products from the factory gate to the ship in 126 countries. The authors identify the effect of time delays in exporting on bilateral trade, using a standard gravity equation controlling for remoteness and a set of instrumental variables to avoid endogeneity related problems. Estimates imply that on average each additional day that a product is delayed prior to being shipped reduces trade by at least 1 percent. A larger effect on timesensitive agricultural goods is reported: a day's delay reduces a country's relative exports of such products by 7 percent on average. The results presented by Djankov et al suggest rather important implications for developing countries seeking to expand exports. The recent Doha trade talks have focused basically on imports barriers in the USA and EU. However, since OECD tariffs are already quite low, estimates of increased exports by developing countries from eliminating them are also relatively small, around 2-10\% according to Amit et al (2005). For the least developed countries, which already have preferential access in several developed markets, the benefits from additional market access are in some cases even negative (Francois et al, 2005). In contrast, Djankov's estimates imply that improving trade facilitation can have relatively large effects on exports. For instance, in sub Saharan Africa it takes 48 days on average to get a container from the factory gate loaded on to a ship. Reducing export times by 10 days is likely to have a bigger impact on exports (expanding them by about 10\%) than any feasible liberalization in Europe or North America. In contrast, estimates by Anderson et al (2004), show that world exports would increase by about $10 \%$ if there was complete global trade liberalization.

According to Hummels (2007), ocean shipping, which constitutes 99 percent of world trade by weight and a majority of world trade by value, experienced a technological revolution in the form of container shipping, but dramatic price declines are not in evidence. Instead, prices for ocean shipping exhibit little change from 1952-1970, substantial increases from 1970 through the mid-1980s, followed by a steady 20year decline. That is not to say that the container revolution was unimportant; after all, estimates in the 
paper suggest that increasing the share of trade that is containerized lowers shipping costs from 3 to 13 percent. However, these savings were trumped in the 1970s by sharp increases in fuel and port costs. Indeed, ocean freight costs in recent years have again begun to increase with the cost of crude, and port congestion has become an especially severe problem in those countries with rapidly growing trade volumes.

As far as we are concerned, the work by Haddad and Hewings (2005) constitutes the first attempt to estimate the role of transportation costs on the Brazilian interregional trade performance, in a general equilibrium analytical framework, in the presence of economies of scale. A unique feature of the CGE model developed by the authors is the explicit modeling of the transportation services and the costs of moving products based on origin-destinations pairs. The model is calibrated taking into account the specific transportation cost structure of each commodity flow, providing spatial price differentiation, which indirectly addresses the issue related to regional transportation infrastructure efficiency.

The model developed in this paper is a natural extension of the B-MARIA-27 model described in Haddad and Hewings (2005). More details about the class of B-MARIA models can be found in the seminal works of Haddad and Hewings (1997) and Haddad (1999). The original framework is extended in such a way that port efficiency and maritime transport costs are accommodated and have its impact on the Brazilian interregional and foreign trade performance fully traced out. The extended model thus allows a complete characterization of the role played by import barriers as well as the interplay between scale economies and the distribution of the gains from trade, under an economic environment where the modeling of land transport costs allows geography to influence interregional trade relations.

The remainder of this paper is organized as follows: first, the general features of the extended model will be presented, where special emphasis will be given to the modeling issues related to the introduction of maritime transport costs and port efficiency in foreign trade relations. Secondly, the simulation strategy will be detailed, with a general description of the closures used in each scenario under investigation. The subsequent section will thus be devoted to the discussion of the main results and the final section will set up a synthesis with the main conclusions drawn up from this exercise.

\section{General Features of the Model}

The model recognizes the economies of 27 Brazilian states. Agents' behavior is modeled at the regional level, so that variations in the structure of regional economies can be accommodated. Results are based on a bottom-up approach, i.e. national results are obtained from the aggregation of regional results. The model indentifies eight sectors in each state producing eight commodities, one representative household in each state, regional governments and one Federal government, and a single foreign consumer who trades with each state. Government finances are considered, as well as regional labor markets. The model is structurally calibrated for 2002.

The effects of import cost reductions are evaluated in the short-run scenario. This implies interindustry and interregional immobility of capital, fixed regional population and labor supply, fixed regional wage differentials, and fixed national real wages. On the demand side, investment expenditures are fixed, implying the usual CGE modeling assumption that investment reevaluation is not a short-run decision for firms. Household consumption follows household disposable income, and government consumption, at both regional and federal levels, is fixed. 


\section{Modeling Issues: Scale Economies, Land-Maritime Transportation and Port Efficiency}

Two previous important extensions were made in the microeconomic structure of the seminal B-MARIA model and its details can be found in Haddad and Hewings (2005). The first attempted to develop a more flexible functional form for the manufacturing sector production function in each of the 27 Brazilian states to incorporate non-constant returns to scale, a fundamental assumption for the recent theoretical developments of the New Economy Geography. The modeling trick has its roots in the work of Whalley and Trela (1986), where increasing returns are incorporated in an industry production function through parametric scale economy effects, exploring local properties of the CES production function. Local convexity properties of the functional forms are retained in order to guarantee, from the theoretical point of view, the existence of the equilibrium. Changes in the production system were introduced only in the manufacturing sector, as data were available for the estimation of the relevant parameters. The second major extension in the structure of B-MARIA was the formal inclusion of transportation margins to account for the real costs of moving goods from one region to another. Regional transportation sectors are considered and assumed to operate under constant returns to scale (nested Leontief/CES production function), using as inputs composite intermediate goods - a bundle including similar inputs from different sources - in accordance with the usual Armington assumption for CGE models. Locally supplied labor and capital are the primary factors used in the production process. The sectoral production meets margin and non-margin demands, serving both domestic and international markets.

Beyond the modeling of land transport costs - as an additional cost in foreign and interregional trade relations - and non-constant returns to scale in the regional manufacturing sectors, this work adds two new features to the model which are particularly relevant to the case of Brazil. Low public investment expenditures in infrastructure trough the last three decades has significantly increased import costs in Brazil, specially due to the magnification of port inefficiencies as well as maritime transport costs. In order to have a good grasp of how important are these two cost components to the final price paid by Brazilian importers and consequently to the decision to import, port efficiency and maritime transport costs should somehow be modeled.

The modeling strategy assumed specific maritime transport cost to be an exponential function of the distance between the foreign port of origin and the domestic port of entry. The exponential form was chosen in order to capture any scale effects in transportation, in the form of long-haul economies. Clearly, this strategy does not accommodate for variations in specific transportations costs due to differences in the characteristics of the products being imported. Our first guess is that such variations, while they do exist, will not be huge enough to interfere in our main results. Maritime transport cost was considered to be the difference between CIF (cost, insurance and freight) and FOB (free on board) prices paid by Brazilian importers. Information on the value of Brazilian imports by country of origin, port of entry, mode of transportation and state of destination can be easily found in the governmental site of the Ministry of Industry, Development and Trade. With available information for regional imports in 2002 and real distances between ports approximated by euclidian distances, a specific maritime transport cost function could be estimated. A maritime transport cost index was then built for each of the 27 Brazilian states, according to a weighted average of estimated transportation costs comprising all regional imports, where weights were defined as the share of each flow of imports on the total regional imports. In order to simulate generalized gains in efficiency in the (international) maritime transportation sector, estimated parameters were modified in such a way that specific maritime transport costs were reduced up to a certain pre-defined amount for all national origin-destination pairs.

Regional port costs were measured as the share of transportation expenditures (other than land transport costs and time barriers) over the total CIF value of regional imports. This information is readily available from the interstate input-output database for 2002. The microeconomic structure of the transportation sector can easily accommodate improvements in port efficiency through the modeling of positive technological shocks, reducing the margin costs over CIF import values up to a pre-defined amount. 


\section{Describing the Basic Experiment}

In the next section the main results from the simulations are presented. The basic experiment consisted of the evaluation of an overall reduction in foreign import barriers. Accordingly, import barriers are assumed to comprise three different, though correlated, components of import costs, i.e. tariff barriers, maritime transport costs and port costs. An appraisal of the relative importance of those three components - as the way each of them can influence the country economic landscape - may bring some useful insights for future trade policy analysis as well as some guidelines for sound investment decisions in public infrastructure.

Three basic simulations were carried out and results were subjected to analytical comparisons. For import tariffs, an overall $25 \%$ reduction was implemented. As for the case of maritime transportation and ports costs, a $25 \%$ gain in efficiency was then simulated.

The way the economy landscape is affected by generalized reductions in import barriers will depend on which component of import costs is reduced. However, in all the three scenarios under consideration domestic relative prices will be altered in such a way that import competition will be favored, as the economy opens up to trade. Overall efficiency in resource allocation will be improved and, by the same token, gains from trade will take national welfare a step up.

Notwithstanding the aggregate benefits from improved foreign trade relations, regions might be adversely affected through re-orientation of trade flows - trade diversion - as relative accessibility changes in the system. Thus aggregate gains from trade are not necessarily accompanied by generalized gains in welfare. This issue of trade diversion versus trade creation has been an important one in the international trade literature, especially in the case of welfare evaluations of preferential trade agreements. It extends naturally to regional models where interregional trade relations are at the center stage.

\section{Results}

The analysis of the simulation results will concentrate on the short-run effects. Special emphasis will be given to the relevant macro variables that may help to clarify the functioning mechanism of the model. Spatial effects considering changes in welfare and real GDP will be also presented. Secondly, robustness of the results is evaluated for the key parameters related to the simulation exercises, namely, foreign trade elasticities and parameters to scale economies. To reach this goal, systematic sensitivity analysis will be carried out.

Finally, in an attempt to better understand the role of increasing returns in the economic geography of an integrated interregional system, the parameter of scale economies is adjusted in the São Paulo manufacturing sector. The idea is to check whether, in the Brazilian case, with reductions in import barriers, the São Paulo firms have a competitive advantage to further exploit scale economies, therefore stimulating even further the concentration of economic activity in the already richer and more developed region in the country.

\subsection{Basic results}

Table 1 summarizes the basic aggregate results. As imports barriers are partially reduced, efficiency in resource allocation is improved and aggregate gains from trade (gains in welfare) are positive for the three scenarios under evaluation. Local sectors are more exposed to foreign competition and domestic price indexes are decreased, benefiting more competitive firms and consumers in general, as intermediary products as well as final goods become cheaper. A more open and internationally competitive economy 
intensifies its trade relations with the rest of the world, exporting and importing greater volumes of products and services.

Brazil is still considered a relatively closed economy, where import tariffs can reach high levels, especially for its historically protected manufacturing sector, a by-product of post world war II importsubstitution industrialization policies. Aggregate simulation results seem to confirm that. Except for the relatively inefficient local manufacturing sector, overall marginal benefits from import tariff reduction can be significantly higher than marginal benefits from increasing efficiency in maritime transportation and port sectors.

Table 1. Short-run aggregate results (in percentage-change)

\begin{tabular}{|c|c|c|c|}
\hline & Import tariffs (\%) & Maritime transp. costs (\%) & Port efficiency (\%) \\
\hline \multicolumn{4}{|l|}{ Activity level } \\
\hline Agriculture & 0.0257 & 0.0176 & 0.0077 \\
\hline Manufacturing & -0.0100 & 0.0087 & 0.0106 \\
\hline Utilities & 0.0160 & 0.0096 & 0.0024 \\
\hline Construction & 0.0017 & 0.0006 & -0.0005 \\
\hline Trade & 0.0411 & 0.0196 & 0.0047 \\
\hline Financial institutions & 0.0481 & 0.0292 & 0.0142 \\
\hline Public administration & 0.0135 & 0.0081 & 0.0030 \\
\hline Transportation and other services & 0.0593 & 0.0120 & -0.0237 \\
\hline \multicolumn{4}{|l|}{ Prices } \\
\hline Investment price index & -0.5849 & -0.3656 & -0.1226 \\
\hline Consumer price index & -0.4419 & -0.3185 & -0.1357 \\
\hline Exports price index & -0.4838 & -0.2963 & -0.1065 \\
\hline Imports price index & - & -0.9805 & - \\
\hline GDP price index, expenditure side & -0.5022 & -0.2834 & -0.1400 \\
\hline National terms of trade & -0.4862 & 0.6879 & -0.1070 \\
\hline \multicolumn{4}{|l|}{ Primary factors } \\
\hline Aggregate payments to capital & -0.3021 & -0.2279 & -0.1212 \\
\hline Aggregate payments to labor & -0.3837 & -0.2904 & -0.1398 \\
\hline Aggregate capital stock, rental weights & - & - & - \\
\hline $\begin{array}{l}\text { Aggregate employment, wage bill } \\
\text { weights }\end{array}$ & 0.0587 & 0.0283 & -0.0041 \\
\hline \multicolumn{4}{|l|}{ Aggregate demand } \\
\hline Real household consumption & 0.0538 & 0.0266 & 0.0077 \\
\hline Aggregate real investment & - & - & - \\
\hline Aggregate real Reg. gov. demand & - & - & - \\
\hline Aggregate real Fed. gov. demand & - & - & - \\
\hline Export volume & 1.0089 & 0.6248 & 0.2238 \\
\hline Import volume & 1.0067 & 0.6240 & 0.0635 \\
\hline \multicolumn{4}{|l|}{ Aggregate indicators } \\
\hline Eq. variation-total (change in \$) & 1716.88 & 867.35 & 245.61 \\
\hline Real GDP & 0.0203 & 0.0083 & 0.0150 \\
\hline
\end{tabular}

Regarding import infrastructure, simulation results seem to indicate that maritime transport costs may play a more important role than port costs in the decision to import. Although results for both import costs components are qualitatively similar, efforts on the reduction of ocean transport costs seem to bring higher returns for the economy as a whole. Although short-run real GDP growth may be more stimulated when port efficiency is improved, that result seems to be more the consequence of a less active import sector than to be related to improvements in the allocation of resources. A more active import sector in the scenario where maritime freight rates are reduced is more likely to contribute to higher GDP growth rates in the long-run, as investment rates are stimulated by lower capital costs.

Reductions in import barriers will affect labor markets and national employment figures will benefit from GDP growth, exception made for the simulation of gains in port efficiency. In that case, a less intensive 
use of primary factors - especially labor since capital demand is fixed - per unit of imports will counterbalance higher labor demand from GDP growth. Net effects for employment figures will thus be negative.

Results in Table 2 concentrate on efficiency and welfare spatial effects. As expected, regional results seem to confirm aggregate results in terms of the relative importance of each of the import costs components under evaluation. Basically, all regions in the country benefit from overall reductions in import barriers. Stronger import competition guarantees lower prices for consumers in importing regions, especially for the greatest importing regions in the country like the south and southeast regions. Lower prices in importing regions will also benefit consumers in more remote regions in the country, like the north region, trough enhanced interregional trade linkages. Negative regional welfare effects seem to be related to trade diversion due to interregional trade re-orientation.

Regional welfare and efficiency effects are stronger when import tariffs are cut. Regarding import infrastructure, greater regional welfare effects take place when ocean transport costs are reduced. A more active importing sector translates import competition into lower market prices, benefiting consumers throughout the economy. Again, it turns out that overall improvement in port efficiency plays a more important role for regional GDP growth than overall ocean transport cost reductions. The same considerations made for results in Table 1 will apply.

Table 2. Spatial results: Relative Equivalent Variation and Regional Growth

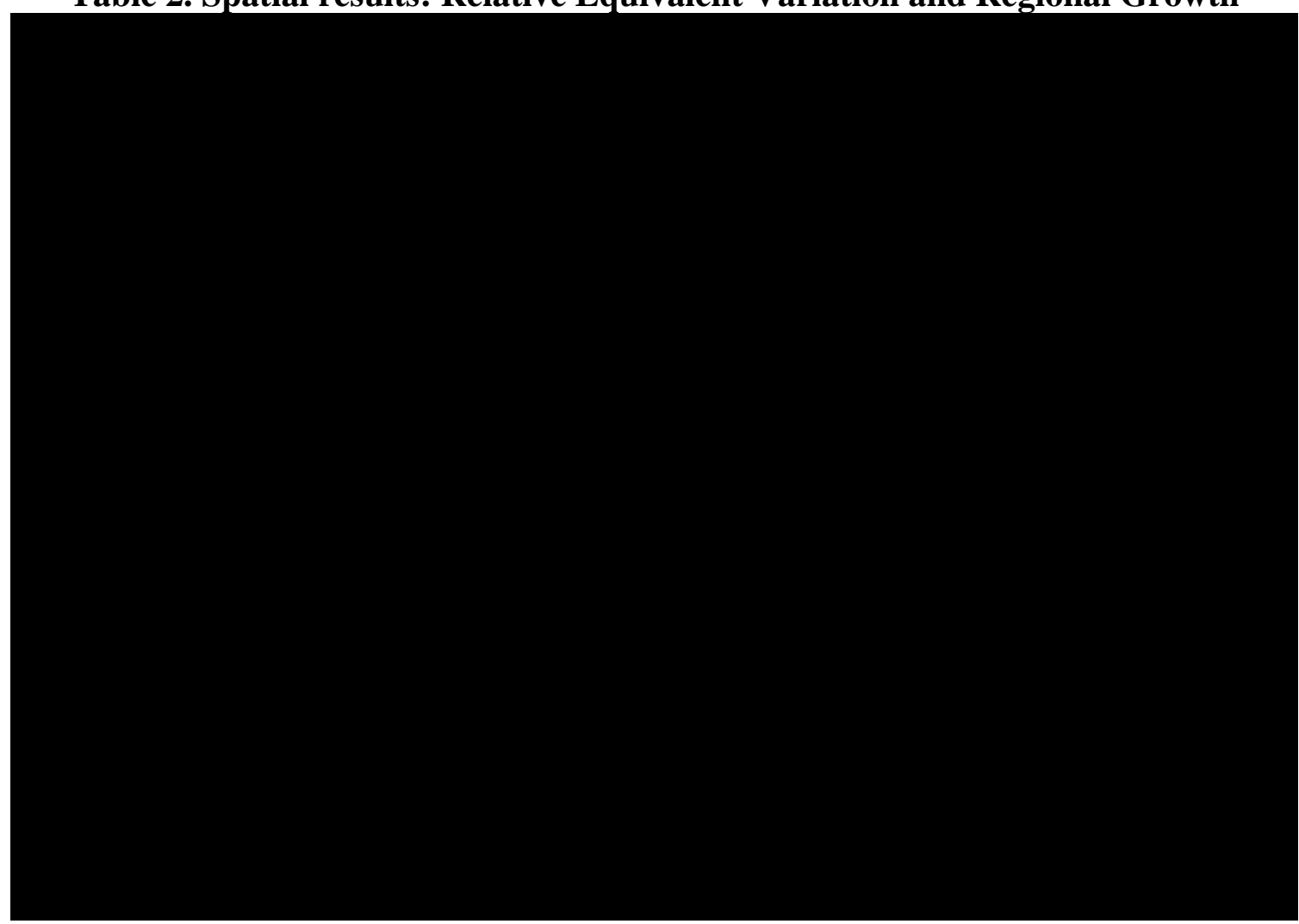

Obs. GDP is measured as a percentage-change in real terms

\subsection{The role of increasing returns}

The introduction of increasing returns to scale in AGE models has long been a challenge for empirical analysts. Traditional AGE models designed for trade policy analysis usually assume perfect competitive markets, where gains from trade can be quite well underestimated. 
The New Trade Theory together with the recent proliferation of preferential trade agreements brought new stimulus to the design of AGE models under an imperfect competitive framework. Also, recent theoretical advances in the so called New Economy Geography (NEG) raised new issues for trade policy analysts, such as how to accommodate the role of agglomeration and dispersions forces when a country opens up to foreign trade.

Qualitative sensitive analysis is carried out in this sub-section in order to grasp a better understanding on the role played by the introduction of non-constant returns to scale in the modeling framework. More specifically, the goal here is to assess the role played by increasing returns in the manufacturing sector in the state of São Paulo, the most industrialized state in Brazil and for which there is evidence that it is the focal point of agglomeration economies in the country. More recent figures for the state of São Paulo show that it was responsible for over $40 \%$ of Brazilian imports and over $40 \%$ of national manufacturing activity in 2007.

The predominance of agglomeration forces can lead to exacerbation of domestic regional inequalities, especially when economic activity is unevenly distributed across the country. NEG models predict that, in the presence of increasing returns and interregional trade costs, firms and workers tend to locate close to large markets (Krugman, 1991). However, as the economy opens up to international trade, forward and backward linkages that arises when manufacturing tries to serve a small domestic market can become much weaker, resulting in a shrinking manufacturing sector and on the de-concentration of economic activity as country liberalizes. Accordingly, closed markets promote huge central metropolises and open markets discourage them. This phenomenon seems to be especially important for trade policy in developing economies (Krugman and Elizondo, 1995).

The interplay between agglomeration and dispersion forces as the Brazilian economy opens up to international trade can be traced out using our modeling framework with a special set of values for the scale economies parameters. In order to isolate the effects of agglomeration forces, constant returns to scale is assumed in every sector in every state. The only exception is the manufacturing sector in the state of São Paulo, for which an interval in the IRTS curve is considered, ranging from high increasing returns ( $\mu=0.5$ ) to high decreasing returns to scale $(\mu=1.5)$, i.e., $\mu \in[0.5,1.5]$ in the manufacturing sector. A series of simulations is run where different values of $\mu$ are assumed in this interval. This experiment was devised in the same spirit as in Haddad and Hewings (2005), where an attempted was made to trace out the role of increasing returns in the context of an improved Brazilian land transportation infrastructure.

Figures 1 to 6 show the results for the three components of imports barriers under consideration. Regarding the role of increasing returns when gains in efficiency for the maritime transportation sector and ports are considered, Figure 1 to 4 shows that, as scale economies gets weaker, gains in efficiency and welfare are decreased not only in São Paulo but also in the country as a whole.

For the case of import tariff reduction, the history goes on the other way around. Figures 5 and 6 show now that, as scale economies gets weaker, gains in efficiency as well as welfare are increased in both São Paulo and the country as a whole.

How can theoretical advances from NEG models help understanding these two apparently conflicting results? As it has been already formally demonstrated by those models backward and forward linkages only become economically meaningful in the presence of sufficiently strong scale economies. Also, there is a fundamental trade-off between transportation costs and scale economies. In the case of Brazil, with its continental dimensions and poor infrastructure, high land transportation costs can hinder further exploitation of scale economies by the São Paulo manufacturing sector, depending on how open is the economy to foreign trade. Improvements in port efficiency or reductions in maritime transportation costs can both increase the access to cheaper intermediate inputs by firms and to final goods by consumers. Lower input costs will benefit the country economy and, in particular, the economy of São Paulo, since it 
improves the ability of regional manufacturing firms to further exploit scale economies and better serve the poorer regions in the country, notwithstanding high interregional transportation costs. This positive effect will be greater the more intensive are scale economies in the manufacturing sector in São Paulo, which helps to explain the observed patterns in Figures 1 to 4.

Generalized efficiency and welfare gains from lower import barriers will be greater the further scale economies can be exploited by manufacturing firms in São Paulo and high interregional transportation costs can be circumvented. However, observed patterns in Figure 5 and 6 suggest a non-linear nature for the relationship between lower import barriers and gains from trade when scale economies and interregional transport costs are simultaneously considered, at least in the short run. For a stronger reduction in import barriers, as seems to be the case when import tariffs are unilaterally cut by $25 \%$, more intensive scale economies in the São Paulo manufacturing firms seems to be related to lower overall gains in efficiency and welfare. In other words, the existence of high interregional transportation costs together with generalized lower enough import barriers seems to increase the spatial influence of relevant external markets and reduce that of local ones, making direct foreign imports of intermediate and final products more profitable for firms and consumers in poorer regions of the country. In the case of our short run analysis, the negative ripple effects of a shrinking manufacturing sector in São Paulo appear to be more severe the greater are the potential for unexploited scale economies in the sector. Stronger scale economies for the manufacturing sector in São Paulo will stimulate a greater volume of imports, hampering regional production and also undermining short run national GDP growth.

Regarding the interplay between trade openness and Brazilian regional inequality, the greater the potential for scale economies exploitation by the São Paulo's manufacturing sector the stronger will be agglomeration forces over diversion forces, potentially exacerbating existing regional inequalities as the country opens up to foreign trade. Results shown in Figures 7 and 8 for improvements in maritime transportation and port services - taking a poor (North) and a rich (Southeast) region in the country - seem to confirm this. As scale economies get more intensive in the São Paulo's manufacturing sector, the Southeast region becomes increasingly better off in terms of its regional output performance. However, as scale economies fades away, it turns out that results for relative regional output performance are reversed and the North region becomes increasingly better off. For less mild reductions in import barriers - as seems to be the case when import tariffs are cut - fiercer market competition can potentially lead to deconcentration of economic activity in the country. Results for regional output performance in the North and Southeast regions are shown in Figure 9 when import tariffs are linearly reduced. In that case, as scale economies get stronger in São Paulo, relative regional output movements tend to favor the poorer region in the country, reflecting the effects of unexploited scale economies in the richer region, brought about by the increasingly spatial influence of relevant external markets. This result is quite in line with the empirical findings of Sanguinetti and Martincus (2005) for trade liberalization in Argentina, where lower sectoral tariffs in the nineties seemed to be associated with de-concentration of industrial activities out of the area surrounding Buenos Aires. 
The role of increasing returns on the interplay between trade openness, national welfare and output growth

Figure 1. Maritime transportation

(EV)

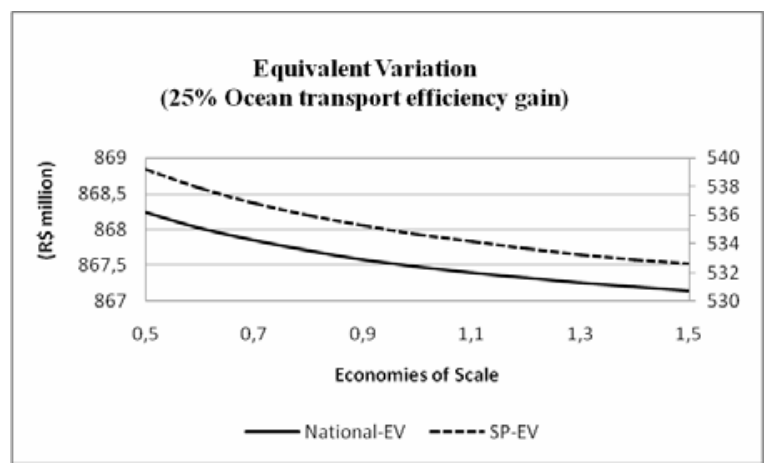

Figure 3. Port Costs

(EV)

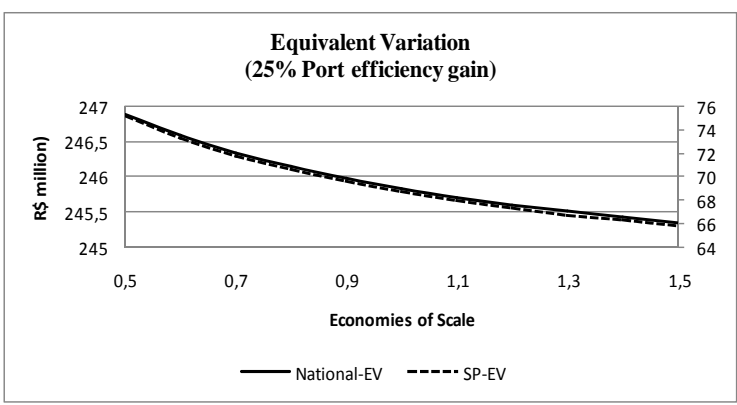

Figure 5. Import Tariffs

(EV)

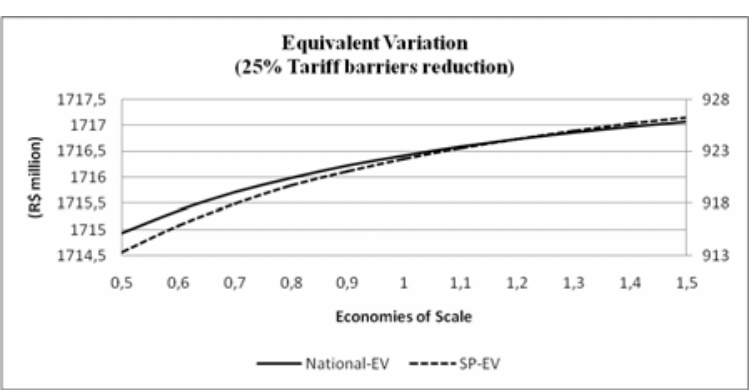

Figure 2. Maritime Transportation (GDP growth)

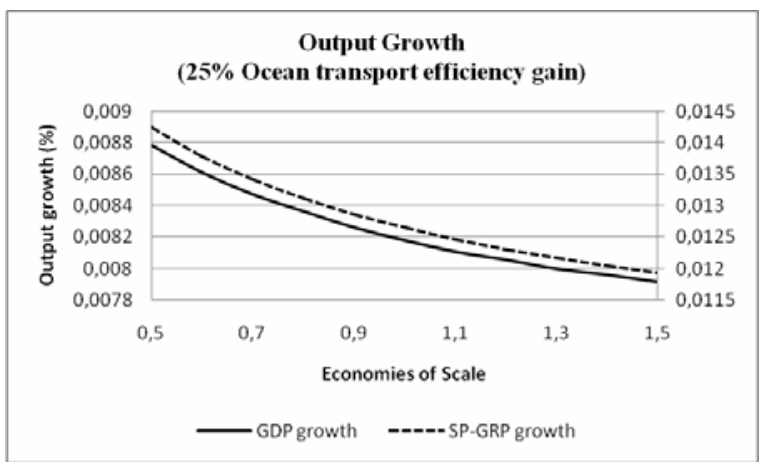

Figure 4. Port Costs

(GDP growth)

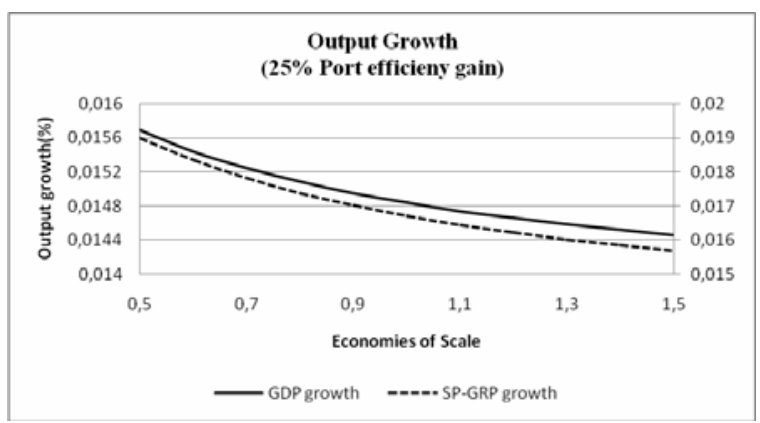

Figure 6. Import Tariffs

(GDP growth)

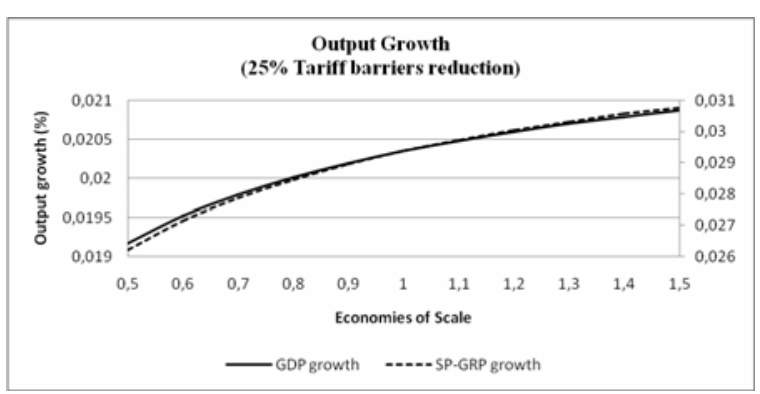


Figure 7. Maritime Transportation (GRP growth)

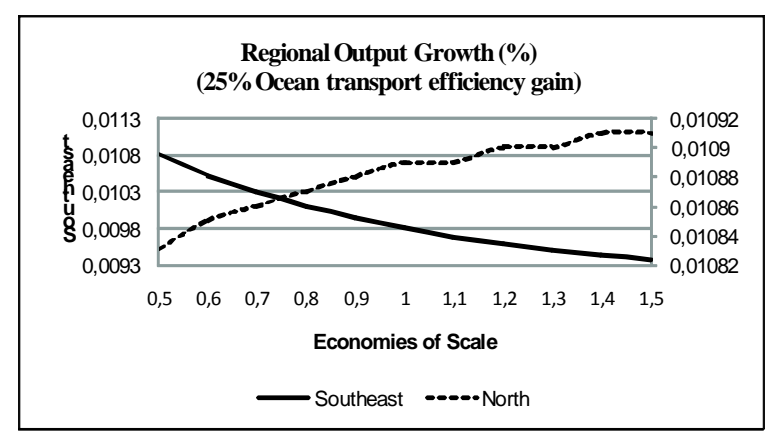

Figure 8. Port Costs (GRP growth)

Figure 9. Import Tariffs

(GRP growth)

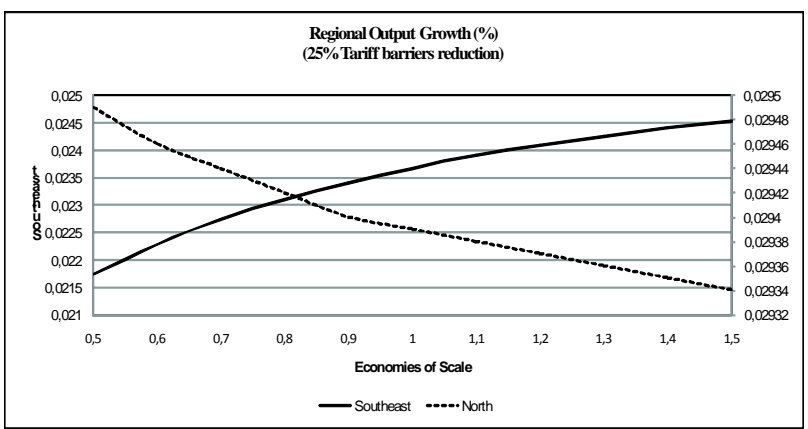

\section{Final remarks}

Since GATT was created in 1947, world exports (as a percentage of global GDP) have increased nearly five times. For most of this period, tariff reduction has been the focus of bilateral and multilateral trade talks among countries worldwide. Recent empirical studies have called the attention to other sources of import costs, such as maritime transportation and port inefficiencies, pointing out how these costs can significantly undermine further progress in international trade, once tariff barriers are increasingly becoming less of a problem.

This seems not to be the case for the Brazilian economy yet. As this modeling exercise has suggested, import tariffs are still the most important component of import barriers for the Brazilian economy trade relations. This is not to say that reductions in maritime transportation costs and improvements in port efficiency are both unimportant for the country trade performance and economic growth. However, once a cost/benefit analysis is considered, it is clear that sound government trade policies should concentrate efforts on trade liberalization in the first place. As this study has shown, even a unilateral trade liberalization that includes Brazilian historically protected manufacturing sector could bring overall benefits to producers and consumers in the country.

Recent advances in NEG models also suggest that declining trade barriers can lead to significant changes in the distribution of industries over space. Due to its continental dimensions and poor infrastructure, the interplay between trade openness and spatial de-concentration is not so clear cut, in the Brazilian case, as 
it seems from theoretical models. Different from other third world metropolises, the manufacturing sector in São Paulo can exploit scale economies without serving a national market. Improvements in port efficiency or reductions in maritime transportation costs both seem to reinforce the competitive advantage of São Paulo's industry relatively to the rest of the country, and then allows those firms to further exploit scale economies both locally and inter-regionally. This result seems to be related to the fact that trade liberalization in the 1990s did not produce any relevant de-concentration of economic activity in Brazil (see Haddad, 1999). However, for less mild reductions in import barriers, such as in the case of a $25 \%$ linear reduction in national import tariffs, it becomes more difficult to draw general conclusions. Our hypothesis is that, for higher degrees of import liberalization, the initial competitive advantage of São Paulo firms may be offset by the increased relevance of more efficient external markets. The less competitive manufacturing sector in São Paulo loses market share not only regionally but also as a supplier to other less developed regions in the country. The existence of unexploited economies of scale in the short run only seems to reinforce this mechanism, since it stimulates substitution away from local products in favor of cheaper imports.

Short run results make it harder to draw parallels with results from NEG models, where production factors are freely mobile in space. We believe that, once this study is carried out for the long run scenario, with free mobility of capital and labor force, other interesting issues will certainly come up. Also, a more comprehensive picture of the role played by maritime transportation costs on national/interregional trade and growth will be made possible once reductions in import/export freights are simultaneously accommodated in the modeling framework. These are promising guidelines that will certainly underpin our future research.

\section{References}

Anderson, J.; Wincoop, E. (2004). Trade Costs. Journal of Economic Literature, Vol. XLII, September, pp. 691-751.

Clark, X.; Dollar, D.; Micco, A. (2004). Port Efficiency, Maritime Transport Costs and Bilateral Trade. NBER working paper 10353.

Clemens, M.; Williamson, J.; (2002). Why Did the Tariff-Growth Correlation Reverse After 1950? NBER working paper W9181.

Djankov, S.; Freund, C.; Cong, P. Trading on Time. World Bank, 2006.

Francois, J.; Meijl, H.V.; Tongeren, F.V. (2005). Trade Liberalization in the Doha Development Round. Economic Policy, 20 (42), 349-391.

Haddad, E. A. (1999). Regional inequality and structural changes: Lessons from the Brazilian experience. Aldershot: Ashgate.

Haddad, E. A.; Hewings, G.J.D. (1997). The Theoretical Specification of B-MARIA. (Discussion Paper REAL 97-T-5). Regional Economics Applications Laboratory University of Illinois at UrbanaChampaign.

Haddad, E. A.; Hewings, G.J.D. (2005). Market imperfections in a spatial economy: some experimental results. The Quarterly Review of Economics and Finance, 45, 476-496.

Hummels, D. (2001a). Toward a Geography of Trade Costs. Working paper, Purdue University.

Hummels, D. (2001b). Time as a Trade Barrier. Working paper, Purdue University. 
Hummels, D. (2007). Transportation Costs and International Trade in the Second Era of Globalization. Journal of Economic Perspectives, 21, 3, pp.131-154. (24).

Krugman, P. (1991). Increasing Returns and Economic Geography. The Journal of Political Economy, Vol. 99, No.3, pp.483-499.

Krugman, P.; Elizondo, R. L. (1996). Trade Policy and Third World Metropolis. Journal of Development Economics, Vol., No.1, pp.137-150.

Limão, N.; Venables, A. J. (2001). Infrastructure, Geographical Disadvantage, Transport Costs, and Trade. The World Bank Economic Review, Vol.15, 3, pp.451-479.

Nordas, H.; Piermartini, R. (2004). Infrastructure and Trade. WTO Economic Research and Statistics Division Staff. Working paper ERSD-2004-04.

Whalley, J.; Trela, I. (1986). Regional Aspects of Confederation (Vol.68). Royal Commission on the Economic Union and Development Prospects for Canada. Toronto: University of Toronto Press. 